\title{
Effect of Somatomedin-C/Insulin-Like Growth Factor I and Growth Hormone on Cultured Growth Plate and Articular Chondrocytes
}

\author{
S. B. TRIPPEL, M. T. CORVOL, M. F. DUMONTIER, R. RAPPAPORT, H. H. HUNG, AND \\ H. J. MANKIN \\ Department of Orthopedics, Massachusetts General Hospital, and Harvard Medical School, Boston, \\ Massachusetts 92114, and Unité de Recherches en Biologie et Pathologie de la Croissance at du Développement, \\ INSERM 7-30, Hôpital des Enfants-Malades, 149 Rue de Sèvres, 75743 Paris Cedex 15, France
}

\begin{abstract}
To determine whether growth hormone has a direct effect on skeletal tissues not mediated by somatomedins, and to better define the role of somatomedin-C/ insulin-like growth factor I (Sm-C/IGF-I) in skeletal development, bovine growth plate, and rabbit articular and growth plate chondrocytes in primary culture were evaluated under a variety of experimental conditions designed to elicit growth hormone and Sm-C/IGF-I stimulation. Under none of these conditions did bovine growth plate chondrocytes respond to either homologous bovine growth hormone or heterologous hGH. Under the same conditions, these cells were highly responsive to human Sm-C/IGF-I with respect to both $\left[{ }^{3} \mathrm{H}\right]$ thymidine and $\left[{ }^{35} \mathrm{~S}\right]$ sulfate incorporation, indices of mitotic and differentiated cell functions, respectively. Similarly, both rabbit articular and growth plate chondrocytes showed enhanced incorporation of $\left[{ }^{3} \mathrm{H}\right]$ thymidine and ${ }^{35}$ S]sulfate in the presence of Sm-C/IGF-I, but did not respond to either native or recombinant hGH. Cells at different stages of maturation within the bovine growth plate differed in their reaction to $\mathrm{Sm}-\mathrm{C} / \mathrm{IGF}-\mathrm{I}$ with proliferative zone cells manifesting a greater response to the peptide than cells of the reserve zone. These results suggest that the action of Sm-C/IGF-I on growth plate and articular chondrocytes is direct and that the effect of GH on these cells is indirect. The data further suggest that within the growth plate, the transition from reserve to proliferative status is associated with an increased $\mathrm{Sm}-\mathrm{C}$ / IGF-I responsiveness, a change which may contribute to the functional differences in these cells. (Pediatr Res 25: 76-82, 1989)
\end{abstract}

\section{Abbreviations}

Sm-C/IGF-I, somatomedin-C/insulin-like growth factor-I bGH, bovine growth hormone

DMEM, Dulbecco's modified Eagle medium

FCS, fetal calf serum;

GH, growth hormone

met-rhGH, biosynthetic methionyl hGH

In 1957, Salmon and Daughaday (1) suggested that the stimulatory effect of growth hormone on cartilage sulfation is indirect

Received July 13, 1987; accepted September 13, 1988.

Correspondence Stephen B. Trippel, M.D., Orthopedic Research Laboratories, Jackson 10th Fl., Massachusetts General Hospital, Fruit Street, Boston, MA 02114. Supported in part by USPHS Research Grant AM 31068 and an Orthopaedic Research and Education Foundation Zimmer Career Development Award, and by grants from the Institut National de la Santé et de la Recherche Médicale. and mediated by a circulating GH-dependent factor now known as somatomedin-C or insulin-like growth factor I (Sm-C/IGF-I). The postulate that the stimulatory effects of growth hormone on skeletal growth are somatomedin-mediated arose from this and other early work $(2,3)$ and has come to be known as the somatomedin hypothesis. Most studies investigating the relationships between GH, somatomedin, cartilage, and growth have supported this hypothesis (1-12). In contrast, recent data suggest that the action of GH on chondrocytes is a direct one (13-19). As a result, the mechanism by which these hormonal factors regulate skeletal growth has become controversial.

Several in vivo studies have demonstrated longitudinal limb growth in rats receiving hGH injected directly into the tibial growth plate $(13,16)$ or the limb vasculature (19). Perhaps the most compelling evidence for a direct effect of $\mathrm{GH}$ on cartilage is the finding by Madsen et al. (14) that proliferation of cultured lapine ear and rib chondrocytes in culture is stimulated by hGH. The results of these studies are consistent with a direct $\mathrm{GH}$ effect, but are also consistent with an indirect effect of $\mathrm{GH}$ mediated by local GH-dependent somatomedin production. Such an autocrine or paracrine model for stimulation of growth has received support from several lines of experimental evidence $(20,21)$. Green et al. (22) have recently proposed an alternative model for GH and Sm-C/IGF-I actions in which GH promotes differentiation of stem cells, rendering them responsive to stimulation of proliferation by Sm-C/IGF-I. Although support for this dual effector theory has been obtained for certain cell types (23), its application to skeletal growth has not been established.

To characterize the respective effects of Sm-C/IGF-I and GH on both articular and growth plate cartilage, the present studies sought first to reproduce the "direct" in vitro GH effect on physeal and articular chondrocytes to determine whether this effect is mediated by somatomedin in a local autocrine or paracrine fashion. If direct, any observed $\mathrm{GH}$ action would be expected to be unaffected by experimental conditions influencing autocrine or paracrine Sm-C/IGF-I actions $(24,25)$. These studies also addressed the question whether, as predicted by the dual effector theory, chondrocytes at different stages of maturational development or anatomic derivation buffer with respect to SmC/IGF-I or GH responsiveness.

Our data indicate that $\mathrm{GH}$ does not directly stimulate rabbit articular or physeal chondrocytes or bovine physeal chondrocytes under any of a broad range of experimental conditions. The results also reveal that, under the same conditions, Sm-C/IGF-I stimulates both mitotic and differentiated cell functions in both physeal and articular chondrocytes. Interestingly, different populations of cells within the bovine physis appear to differ in their responsiveness to $\mathrm{Sm}-\mathrm{C} / \mathrm{IGF}-\mathrm{I}$ in a fashion at least partly consistent with the dual effector theory. 


\section{MATERIALS AND METHODS}

Hormones and growth factors. In bovine chondrocyte studies, highly purified preparations of Sm-C/IGF-I were the gift of Dr. Judson J. Van Wyk (Chapel Hill, NC). The Sm-C/IGF-I content of these preparations was determined by RIA (26). For rabbit chondrocytes studies, Sm-C/IGF-I was a gift of Dr. Leo Van den Brande (Utrecht, The Netherlands). hGH for bovine studies was the gift of Dr. Linda Frykland, KABI-AB (Stockholm, Sweden), and hGH for rabbit studies was purchased from Nordisk (2 IU/ $\mathrm{mg}$ ) (Gentoffe, Denmark). Met-rhGH for bovine studies was the gift of Dr. Christopher Rudman, Genentech, Inc. (South San Francisco, CA), and for rabbit studies was obtained from Serono (Geneva, Switzerland). bGH was the gift of the National Hormone and Pituitary Program (Baltimore, MD).

Bovine physeal chondrocyte culture. Growth plate chondrocytes were isolated from the fresh (approximately $2 \mathrm{~h}$ postmortem) physes of 1 - to 2 -wk-old calves by modification of previously described techniques (7). After sterile preparation of the distal radius, the distal radial physis was dissected from surrounding bone, and the perichondrium was completely excised. The harvested cartilage was diced in DMEM, and cells were isolated by sequential exposure to DMEM containing 0.08 hyaluronidase (Sigma Chemical Co., St. Louis, MO) for $20 \mathrm{~min}, 0.2 \%$ trypsin (Worthington Biochemicals, Freehold, NH) for $40 \mathrm{~min}$, and $0.1 \%$ collagenase (Sigma) with $5 \%$ calf serum (GIBCO, Grand Island, NY) overnight. Cells were filtered through nylon mesh (pore size, $125 \mu \mathrm{m}$ ) to remove matrix debris and cell aggregates. The cell suspension (approximately $0.5 \times 10^{6}$ cells $/ \mathrm{ml}$ ) was layered in $20-\mathrm{ml}$ aliquots onto $11 \mathrm{ml}$ Ficoll/Hypaque $(10 \% /$ $11 \%)$ in $50-\mathrm{ml}$ centrifuge tubes. After centrifugation at $200 \times \mathrm{g}$ for $6 \mathrm{~min}$ to remove undigested matrix fragments, the cells were recovered from the medium-gradient interface, washed once in PBS, pH 7.4, and resuspended in a 1:1 (vol:vol) mixture of F-12 medium (GIBCO) and DMEM containing 10\% heat-inactivated newborn calf serum (GIBCO), $50 \mu \mathrm{g} / \mathrm{ml} \mathrm{L-ascorbate,} 50 \mathrm{U} / \mathrm{ml}$ penicillin $\mathrm{G}$, and $50 \mu \mathrm{g} / \mathrm{ml}$ streptomycin sulfate. Cell number was determined by a hemocytometer and viability by trypan blue exclusion.

To test the effect of $\mathrm{GH}$ on these physeal chondrocytes, the method of Madsen et al. (14) was used. Cells were plated at $3 \times$ $10^{5}$ cells $/ \mathrm{cm}^{2}$ in triplicate or quadruplicate 24 - or 96 -well plates and incubated overnight at $37^{\circ} \mathrm{C}$ in an atmosphere of air containing $5 \% \mathrm{CO}_{2}$ to allow cell attachment. The next day, the medium was changed to serum-free MCDB-104 medium (GIBCO) containing $100 \mu \mathrm{g} / \mathrm{ml}$ gentamycin and cells preincubated for 24-48 h. After preincubation, medium was changed to MCBD-104 containing GH, Sm-C/IGF-I, serum, or no additives as designated. At 6 or $24 \mathrm{~h}$ before the end of incubation, $8 \mu \mathrm{Ci}$ / $\mathrm{ml}\left[{ }^{3} \mathrm{H}\right]$ thymidine (New England Nuclear, Boston, MA) was added to the medium. Cells were washed $3 \times$ with PBS, pH 7.4, and $2 \times$ with $5 \%$ trichloroacetic acid and 3:1 (vol:vol) ethanol/ ethyl ether. Isotope incorporation was determined by liquid scintillation counting of solubilized cells or by whole mount autoradiography of cells fixed in situ in a solution of $3 \%$ glutaraldehyde, $0.1 \% \mathrm{M}$ sodium cacdylate- $\mathrm{HCl}$ and $0.05 \mathrm{M}$ sucrose, pH 7.3.

Statistical analysis of data was performed with the two-tailed $F$-test using the Statistical Analysis System package provided by the Massachusetts General Hospital Department of Biostatistics.

Rabbit chondrocyte culture. Prepubertal Fauve de Bourgogne rabbits (Ruvel, France) were killed by a sharp blow on the head and shaved. After several washings with $70 \%$ alcohol, a section of ventral skin was taken and long bones were quickly removed. Muscles, aponeurosis, and periosteum were removed from the bones, and articular and growth plate cartilage were harvested. Cartilage slices and the sample of ventral skin were further cut into small pieces. Tissues were then subjected to enzymatic digestion by a modification of the above cell isolation procedure (27). The resulting cell suspension was plated into $25-\mathrm{cm}^{2}$ flasks at a concentration of $8 \times 10^{4}$ cells/flask in $4 \mathrm{ml} \mathrm{Ham}$ 's F12 medium containing 10\% FCS (Boehringer Mannheim), $100 \mathrm{IU} /$ $\mathrm{ml}$ penicillin and $100 \mu \mathrm{g} / \mathrm{ml}$ streptomycin or into 24 -well plates at a concentration of $1 \times 10^{4}$ cells/well in $1 \mathrm{ml}$ of this medium. Cells were incubated at $37^{\circ} \mathrm{C}$ in an atmosphere of $5 \% \mathrm{CO}_{2}$ in air. Medium was changed on days 4 and 7 . Under these conditions, both types of chondrocytes and skin fibroblasts became confluent on day 9.

In designated experiments with articular chondrocytes, the day 7 medium change was to serum-free MCDB-104 supplemented with $100 \mathrm{ng} / \mathrm{ml}$ fibroblast growth factor, $5 \mu \mathrm{g} / \mathrm{ml}$ transferrin, 4 $\mathrm{ng} / \mathrm{ml}$ sodium selenite, $2 \mu \mathrm{g} / \mathrm{ml}$ human fibronectin, and $1 \mathrm{mg} /$ $\mathrm{ml}$ pure albumin. Under these conditions, rabbit articular chondrocytes become confluent on day 12 .

To measure $\left[{ }^{3} \mathrm{H}\right]$ thymidine incorporation, chondrocytes or skin fibroblasts grown in primary culture were treated according to Madsen et al. (14). On day 7 of $10 \%$ FCS cultures and on day 10 of serum-free cultures, shortly before confluence, the medium was removed, the cells washed, and the medium replaced with serum-free MCDB-104 for $20 \mathrm{~h}$. After this preincubation period, the medium was changed to fresh MCDB-104 containing either $\mathrm{hGH}$ at concentrations ranging between $20-200 \mathrm{ng} / \mathrm{ml}$ or buffer alone. Cells were then incubated for an additional $24 \mathrm{~h}$. At $6 \mathrm{~h}$ before the end of incubation, $\left[{ }^{3} \mathrm{H}\right]$ thymidine $5 \mu \mathrm{Ci} / \mathrm{ml}$ was added to quadruplicate flasks of each group. At the end of the incubation, the cells were washed three times with calcium and magnesium-free Gey's balanced salt solution followed by $0.5 \%$ Triton $X 100$. Chondrocytes or fibroblasts were collected on glass fiber filters which were dried and counted in $5 \mathrm{ml}$ of fluor in a Packard $\beta$-spectrometer (Hewlett-Packard Co., Palo Alto, CA).

Four additional identically treated flasks or wells from each group were not labeled with $\left[{ }^{3} \mathrm{H}\right]$ thymidine and were used for measurement of DNA content and cell number. Cells were trypsinized with $0.05 \%$ trypsin and $0.02 \%$ EDTA. An aliquot of the cell suspension was counted by hemocytometer; the remainder was used for DNA measurement according to Burton (28) for $25-\mathrm{cm}^{2}$ flasks and according to Kapuscinski et al. (29) for 24well plates.

Incorporation of $\left[{ }^{35} \mathrm{~S}\right]$ sulfate into proteoglycans was assessed using chondrocytes grown to confluence in 24-well plates. In serum-free defined medium cultures, the incorporation was done on day 12 . In $10 \%$ FCS cultures, the medium was changed to serum-free DMEM for $20 \mathrm{~h}$ on day 8 . Cells were then incubated in serum-free, sulfate-free DMEM in the presence of $1.5 \mu \mathrm{Ci} / \mathrm{ml}$ $\mathrm{Na}^{35} \mathrm{SO}_{4}$ with or without hGH $100 \mathrm{ng} / \mathrm{ml}$, or Sm-C/IGF-I 10 $\mathrm{ng} / \mathrm{ml}$. Control flasks contained the corresponding hormone buffers. After a further 6- and 20 -h period of incubation at $37^{\circ} \mathrm{C}$, the incorporation of $\left[{ }^{35} \mathrm{~S}\right]$ sulfate into newly synthesized proteoglycans was measured in both culture medium and the cell layer as previously described (30).

Proteoglycans were separately extracted from the medium and the cell layer at $4^{\circ} \mathrm{C}$ for $20 \mathrm{~h}$ with $3 \mathrm{M}$ guanidinium hydrochloride in $0.5 \mathrm{Tris} \mathrm{HCl}, \mathrm{pH} 7.4$, and dialyzed against $8 \mathrm{M}$ urea in 0.05 $\mathrm{M}$ Tris- $\mathrm{HCl}, \mathrm{pH} 6.5$. The nondialyzable fraction was chromatographed on a DEAE-cellulose column and sulfated proteoglycan subunits were eluted with $2 \mathrm{M} \mathrm{NaCl}$. Aliquots of eluted material were added to fluor and counted in a Packard $\beta$-spectrometer.

Counts were expressed as mean disintegrations per min per well (medium + cell layer) of six similarly treated wells. Data are reported as the mean \pm SEM. The hormone-treated cells are compared to control cells incubated with the corresponding buffer of each hormone used. Statistical significance was determined by Student's $t$ test.

\section{RESULTS}

Bovine growth plate chondrocyte studies. When bovine growth plate chondrocytes cultured in serum-free medium were exposed to $\mathrm{Sm}-\mathrm{C} / \mathrm{IGF}-\mathrm{I}$, stimulation of $\left[{ }^{3} \mathrm{H}\right]$ thymidine incorporation reproducibly occurred at doses of $10 \mathrm{ng} / \mathrm{ml}$ or above $(p<0.01)$. 
No stimulation occurred in the presence of hGH, bGH, or met$\mathrm{rhGH}$ at concentrations to $300 \mathrm{ng} / \mathrm{ml}$. No stimulation or inhibition was observed in the presence of the buffer in which hGH was provided (Fig. 1).

To determine whether the lack of response to growth hormone at these doses was due to a requirement for higher hormone levels, concentrations of hGH to $8 \mu \mathrm{g} / \mathrm{ml}$ and of bGH to 300 $\mu \mathrm{g} / \mathrm{ml}$ were tested. No stimulation was obtained at any dose used (Fig. 2).

To test the possibility that an early, transient stimulatory effect of $\mathrm{GH}$ was being masked with this protocol (effect tested at 48 $\mathrm{h}$ ), the time course of $\left[{ }^{3} \mathrm{H}\right]$ thymidine incorporation in the presence of Sm-C/IGF-I or of bGH was assessed. Sm-C/IGF-I 20 $\mathrm{ng} / \mathrm{ml}$ produced an increase in $\left[{ }^{3} \mathrm{H}\right]$ thymidine incorporation which first appeared approximately $20 \mathrm{~h}$ after onset of exposure and progressed linearly over the 44-h duration of the experiments $(p<0.01)$. Cells exposed to bGH $100 \mathrm{ng} / \mathrm{ml}$ showed no statistically significant difference from those incubated in the presence of serum-free medium alone $(p>0.4)$.

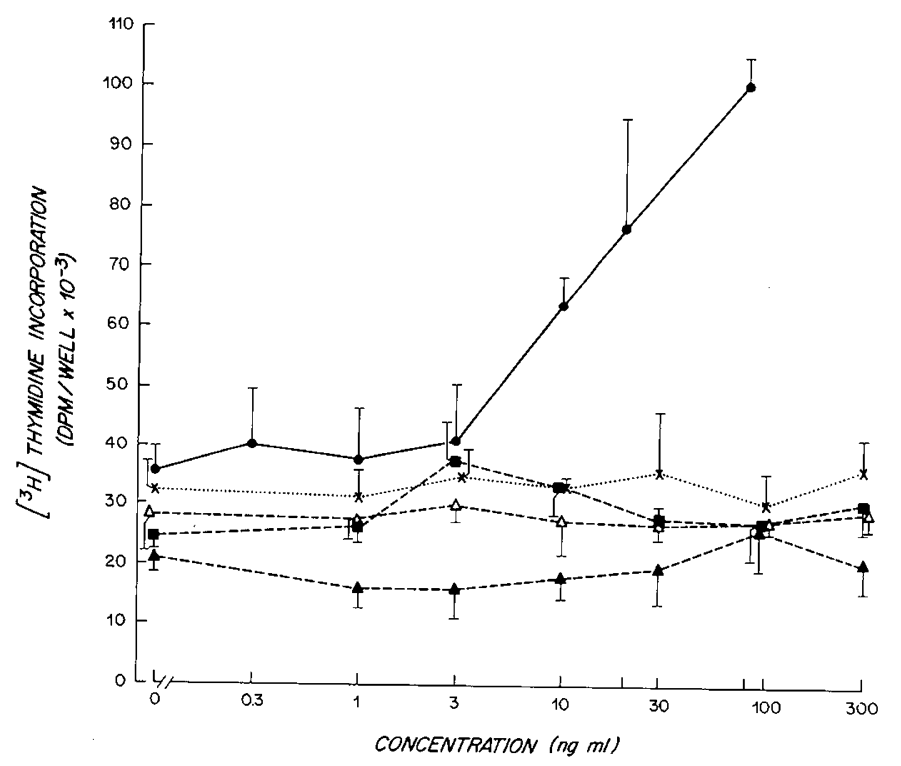

Fig. 1. $\left[{ }^{3} \mathrm{H}\right]$ thymidine incorporation by bovine growth plate chondrocytes exposed for $48 \mathrm{~h}$ to highly purified Sm-C/IGF-I (@), bGH (ם), hGH $(\boldsymbol{\Lambda})$, met-rhGH $(\Delta)$, or buffer $(\times)$. Only Sm-C/IGF-I produced a dose-response curve significantly different from that of buffer $(p<0.01)$.

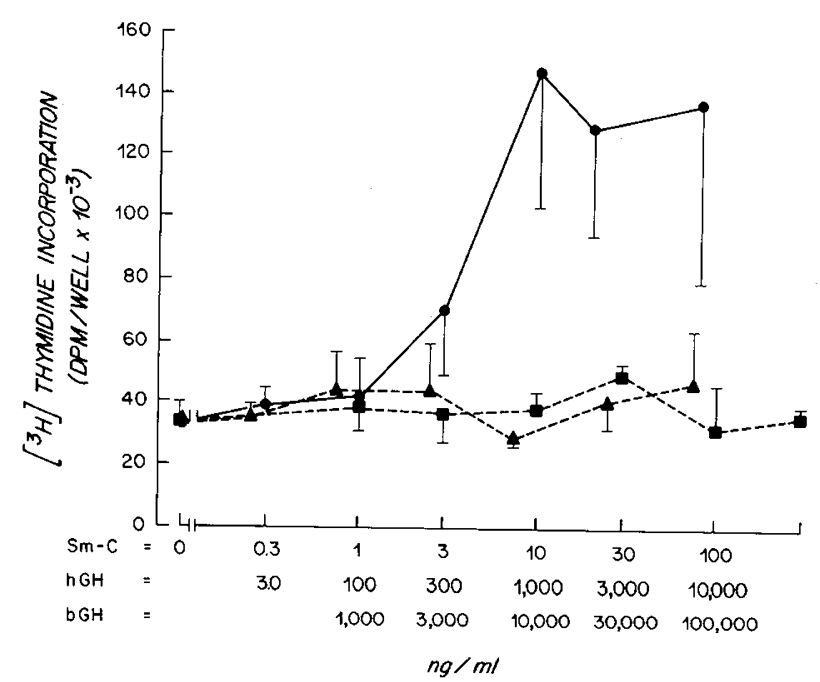

Fig. 2. Incorporation of $\left[{ }^{3} \mathrm{H}\right]$ thymidine by bovine growth plate chondrocytes exposed for $48 \mathrm{~h}$ to exponentially graded concentrations of SmC/IGF-I $(\bullet)$, bGH $(\boldsymbol{\square})$, or hGH $(\boldsymbol{\Lambda})$. The scale of the abscissa for each peptide is indicated in the left margin.
To rule out bGH ineffectiveness due to degradation, utilization by cells, or a short half-life under the conditions of these studies, the time course of $\left[{ }^{3} \mathrm{H}\right]$ thymidine incorporation was reassessed by replacing medium with fresh medium every $2 \mathrm{~h}$. Fresh medium contained the same additives as the original medium. This modification resulted in an enhancement of the Sm-C/IGF-I effect, but no unveiling of a bGH effect (Fig. 3). To ensure that differences in label incorporation were not an artifact of solubilization and scintillation counting techniques, $\left[{ }^{3} \mathrm{H}\right]$ thymidine incorporation was assessed in replicate wells by whole mount autoradiography (see "Materials and Methods"). This technique produced the same results.

To evaluate the possibility that the observed absence of GHinduced stimulation reflected a time requirement for cellular response to $\mathrm{GH}$ greater than that for $\mathrm{Sm}-\mathrm{C} / \mathrm{IGF}-\mathrm{I}$, the duration of exposure to bGH or hGH was increased to 5 days. No stimulation of $\left[{ }^{3} \mathrm{H}\right]$ thymidine incorporation occurred.

It has been previously demonstrated that the different cell populations of the growth plate differ in their binding of $\mathrm{Sm}-\mathrm{C} /$ IGF-I (8) and in their response to Sm-C/IGF-I $(9,31)$. It is thus possible that these populations differ with respect to responsiveness to $\mathrm{GH}$ as well. Because the above studies were conducted with cells derived from whole growth plates, it is possible that the response of a $\mathrm{GH}$-sensitive population of cells was obscured or attenuated by dilution of this population among unresponsive cells. To assess this possibility, distal ulnar physes were separated into reserve and proliferative zones by microdissection, and cells of each zone were isolated as described in "Materials and Methods." Adequacy of zone separation was assessed by histologic analysis of separated zones. Histologic sections demonstrated that a thin region of reserve cells was consistently haryested with the proliferative zone and that contamination of reserve zone cells by proliferative zone cells did not occur. Neither bGH nor $\mathrm{hGH}$ influenced reserve zone cells at any dose tested (Fig. $4 A$ ). The suggestion of slight stimulation of proliferative zone cells by $\mathrm{GH}$ at $3 \mathrm{ng} / \mathrm{ml}$ (Fig. $4 B$ ) was not reproducible in two further repetitions of this experiment. Incorporation of $\left[{ }^{3} \mathrm{H}\right]$ thymidine in the presence of bGH and hGH was not different from controls for either cell type. Stimulation of proliferative zone cells by SmC/IGF-I was more $(p<0.05)$ than of reserve zone cells. Cells from both reserve and proliferative zones were sensitive to Sm$\mathrm{C} / \mathrm{IGF}-\mathrm{I}$ at concentrations as low as $3 \mathrm{ng} / \mathrm{ml}$ (Fig. $4 A$ and $B$ ).

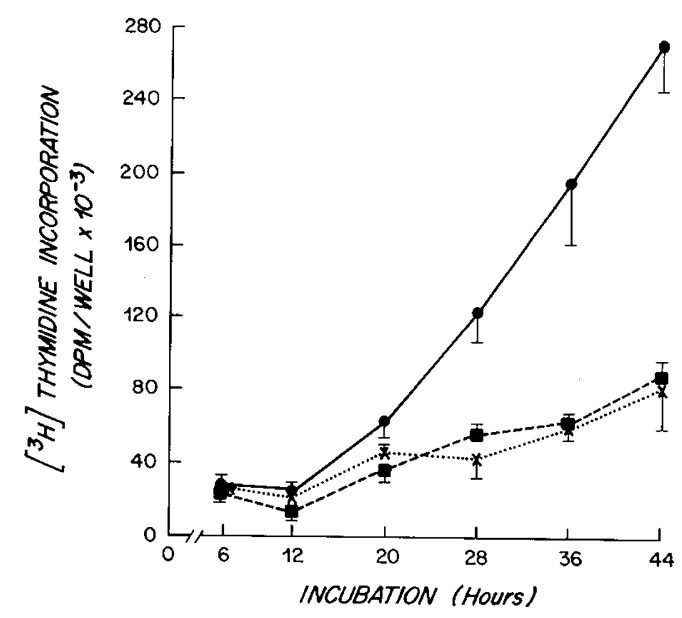

Fig. 3. Time course of $\left[{ }^{3} \mathrm{H}\right]$ thymidine incorporation by bovine growth plate chondrocytes exposed to Sm-C/IGF-I $(\bullet)$, bGH $(\square)$, or no additives $(\times)$. Incubation medium was replaced at $2-h$ intervals during the indicated time period. Incorporation in the presence of Sm-C/IGF-I, but not $\mathrm{bGH}$, was significantly different than that of medium alone $(p<0.01)$. When incubation medium was unchanged during the same time period (data not illustrated), control and bGH effects were superimposable on those shown, and maximal stimulation by Sm-C/IGF-I was half that illustrated. This level of stimulation was still significant $(p<0.01)$. 

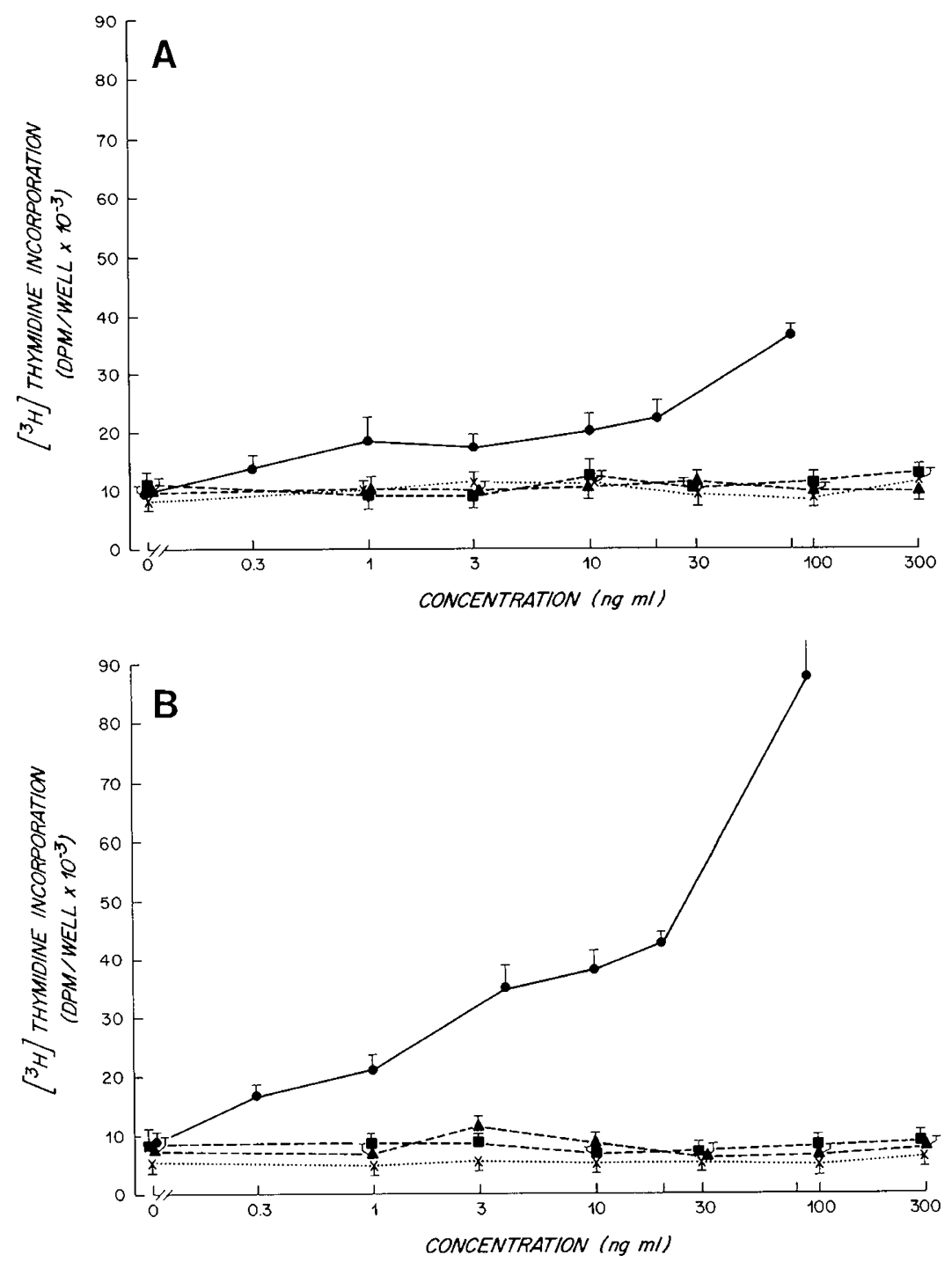

Fig. 4. $\left[{ }^{3} \mathrm{H}\right]$ thymidine incorporation by bovine growth plate reserve zone chondrocytes $(A)$ and by proliferative zone chondrocytes $(B)$ in response to graded doses of Sm-C/IGF-I $(\mathbf{C})$, bGH $(\mathbf{\square}), \mathrm{hGH}(\mathbf{A})$, or buffer $(\times)$. Incubation time in the presence of growth factors was $48 \mathrm{~h}$. The dose-response curve produced by Sm-C/IGF-I, but not bGH or hGH, was significant compared to buffer for both reserve and proliferative zone cells $(p<0.01)$.

To determine whether GH alters differentiated functions of chondrocytes not reflected in DNA synthetic activity, several of the above studies were repeated, testing the effect of $\mathrm{GH}$ on $\left[{ }^{35} \mathrm{~S}\right]$ sulfate incorporation. Experiments were conducted as described for $\left[{ }^{3} \mathrm{H}\right]$ thymidine with the exception that $30 \mu \mathrm{Ci} / \mathrm{ml} \mathrm{Na}{ }^{35} \mathrm{SO}_{4}$ was added $4 \mathrm{~h}$ before termination of incubation. Incubation of bovine growth plate chondrocytes for $48 \mathrm{~h}$ or for 5 days resulted in marked stimulation of sulfate incorporation by Sm-C/IGF-I or fetal bovine serum, respectively. Separated proliferative zone chondrocytes showed a greater response $(p<0.01)$ to highly purified Sm-C/IGF-I than did reserve zone cells (Table 1). In none of the experiments was bGH or hGH stimulatory over the $3-300 \mathrm{ng} / \mathrm{ml}$ dose range tested.

Rabbit chondrocyte studies. When hGH $20-200 \mathrm{ng} / \mathrm{ml}$ was provided to rabbit articular and growth plate chondrocytes for $20 \mathrm{~h}$, no effect was observed as measured by cell count, DNA content, or $\left[{ }^{3} \mathrm{H}\right]$ thymidine incorporation. In contrast, exposure of rabbit skin fibroblasts to $\mathrm{hGH}, 100 \mathrm{ng} / \mathrm{ml}$ for the same time period stimulated cell number by $131 \%$ over control values $(p<$ 0.05 ). DNA content of these cells was not significantly increased (Table 2). In addition, $\left[{ }^{3} \mathrm{H}\right]$ thymidine incorporation by rabbit articular chondrocytes exposed to hGH (all doses) was $595 \pm 34$ $\mathrm{cpm} / \mu \mathrm{g}$ DNA compared to $13,000 \mathrm{cpm} / \mu \mathrm{g}$ DNA for cells incubated with $5 \%$ FCS. [ ${ }^{3} \mathrm{H}$ ] thymidine incorporation by rabbit growth plate chondrocytes was $842 \pm 88 \mathrm{cpm} / \mu \mathrm{g}$ DNA and
$22,800 \mathrm{cpm} / \mu \mathrm{g}$ DNA for cells incubated with hGH and $5 \% \mathrm{FCS}$, respectively.

When articular chondrocytes were incubated in serum-free defined medium from day 7 to day 12 of primary culture, the addition of hGH $100 \mathrm{ng} / \mathrm{ml}$ to the culture medium (replenished every day for 5 days) did not affect cell multiplication (Table 3 ). On the contrary, a significant increase in cell number $(p<0.01)$ and DNA content $(p<0.05)$ was observed in Sm-C/IGF-Itreated versus control cells.

To determine whether GH or Sm-C/IGF-I stimulates differentiated activity of rabbit chondrocytes, the effects of hGH 100 $\mathrm{ng} / \mathrm{ml}$ on $\left.{ }^{35} \mathrm{~S}\right]$ sulfate incorporation was studied in comparison to $\mathrm{Sm}-\mathrm{C} / \mathrm{IGF}-\mathrm{I}$. As illustrated in Figure $5,\left[{ }^{35} \mathrm{~S}\right]$ sulfate incorporation by both rabbit articular and growth plate chondrocytes was significantly stimulated by Sm-C/IGF-I after both 6 and 20 $\mathrm{h}$ of incubation. On the contrary, neither hGH nor met-rhGH was stimulatory at either time point.

When articular chondrocytes, incubated in serum-free MCDB104 from day 7 until day 12 , were exposed to $\left[{ }^{35}\right.$ S] sulfate for the final $20 \mathrm{~h}$ of this period in the presence or absence of the different hormones, hGH did not increase sulfate incorporation (Table 3). In contrast, Sm-C/IGF-I stimulated sulfate incorporation $209 \%$ $(p<0.001)$. Met-rhGH in doses of 50,100 , and $200 \mathrm{ng} / \mathrm{ml}$ similarly had no effect on $\left[{ }^{35} \mathrm{~S}\right]$ sulfate or $\left[{ }^{3} \mathrm{H}\right]$ thymidine incorporation by either rabbit articular of growth plate chondrocytes. 
Table 1. Effect of $b G H$ and Sm-C/IGF-I on $\left[{ }^{35} S\right]$ sulfate incorporation by bovine growth plate chondrocytes*

\begin{tabular}{ccc}
\hline & $\begin{array}{c}\text { Reserve zone } \\
\text { chondrocytes } \\
\text { (cpm/well) }\end{array}$ & $\begin{array}{c}\text { Proliferative zone } \\
\text { chondrocytes } \\
\text { (cpm/well) }\end{array}$ \\
\hline Control & $5,292 \pm 2,251$ & $9,091 \pm 1,518$ \\
$\mathrm{bGH}$ & & \\
$3 \mathrm{ng} / \mathrm{ml}$ & $4,095 \pm 535$ & $7,038 \pm 1,079$ \\
$30 \mathrm{ng} / \mathrm{ml}$ & $3,955 \pm 293$ & $8,474 \pm 398$ \\
$300 \mathrm{ng} / \mathrm{ml}$ & $2,985 \pm 433$ & $8,761 \pm 593$ \\
$\mathrm{Sm}-\mathrm{C} / \mathrm{IGF}-\mathrm{I}$ & & \\
$1 \mathrm{ng} / \mathrm{ml}$ & $5,752 \pm 816$ & $10,010 \pm 724$ \\
$3 \mathrm{ng} / \mathrm{ml}$ & $4,864 \pm 987$ & $11,059 \pm 701 \dagger$ \\
$10 \mathrm{ng} / \mathrm{ml}$ & $5,433 \pm 1,215$ & $12,990 \pm 425 \ddagger$ \\
$30 \mathrm{ng} / \mathrm{ml}$ & $11,910 \pm 487 \dagger$ & $24,776 \pm 2,846 \ddagger$ \\
$80 \mathrm{ng} / \mathrm{ml}$ & $11,080 \pm 1,168 \dagger$ & $28,088 \pm 5,542 \ddagger$ \\
\hline
\end{tabular}

* Bovine growth plate chondrocytes were isolated from microdissected reserve and proliferative zones and plated in quadruplicate 96 -well plates in medium containing $10 \%$ newborn calf serum for $16 \mathrm{~h}$. After preincubation in serum-free medium for $24 \mathrm{~h}$, medium was replaced with fresh serum-free medium containing graded concentrations of bGH or $\mathrm{Sm}$-C/IGF-I for $48 \mathrm{~h}$. At $4 \mathrm{~h}$ before the end of incubation $\left[{ }^{35} \mathrm{~S}\right]$ sulfate, $30 \mu \mathrm{Ci} / \mathrm{ml}$, was added and $\left[{ }^{35} \mathrm{~S}\right]$ sulfate incorpooation assessed. Each treatment group was compared to its additive-free control; statistical significance was determined by $t$ test.

$\dagger p<0.05$.

$\ddagger p<0.001$.

Table 2. Effect of hGH on rabbit articular and growth plate chondrocytes and rabbit skin fibroblasts*

\begin{tabular}{lccc}
\hline & $\begin{array}{c}\text { Cell no. } \\
\left(\times 10^{-6} / \text { flask }\right)\end{array}$ & $\begin{array}{c}\text { DNA } \\
(\mu \mathrm{g} / \text { flask })\end{array}$ & $\begin{array}{c}\left.{ }^{3} \mathrm{H}\right] \text { thymidine } \\
(\mathrm{cpm} / \text { flask })\end{array}$ \\
\hline $\begin{array}{l}\text { Articular chondrocytes } \\
\text { Control }\end{array}$ & $1.082 \pm 0.09$ & $11.14 \pm 1.63$ & $7323 \pm 1316$ \\
$\mathrm{hGH}$ & & & \\
$\quad 20 \mathrm{ng} / \mathrm{ml}$ & $1.123 \pm 0.11$ & $12.34 \pm 1.50$ & $7478 \pm 429$ \\
$40 \mathrm{ng} / \mathrm{ml}$ & $1.124 \pm 0.11$ & $12.05 \pm 1.26$ & $8451 \pm 1134$ \\
$80 \mathrm{ng} / \mathrm{ml}$ & $1.013 \pm 0.07$ & $12.05 \pm 1.38$ & $6211 \pm 658$ \\
$160 \mathrm{ng} / \mathrm{ml}$ & $1.387 \pm 0.13$ & $14.90 \pm 1.41$ & $7153 \pm 1229$ \\
$200 \mathrm{ng} / \mathrm{ml}$ & $1.202 \pm 0.12$ & $12.05 \pm 1.52$ & $7353 \pm 800$ \\
Growth plate chondrocytes & & & \\
Control & $0.82 \pm 0.11$ & $9.44 \pm 1.02$ & $6801 \pm 1418$ \\
hGH & & & \\
$40 \mathrm{ng} / \mathrm{ml}$ & $0.88 \pm 0.12$ & $8.60 \pm 1.40$ & $7182 \pm 1744$ \\
$160 \mathrm{ng} / \mathrm{ml}$ & $0.60 \pm 0.02$ & $7.10 \pm 1.38$ & $6892 \pm 1304$ \\
Skin fibroblasts & & & \\
Control & $2.469 \pm 0.26$ & $30.13 \pm 2.93$ & \\
hGH & & & \\
$100 \mathrm{ng} / \mathrm{ml}$ & $3.240 \pm 0.14 \dagger 38.10 \pm 3.15$ & \\
\hline
\end{tabular}

* Rabbit articular and growth plate chondrocytes and skin fibroblasts in serum-free culture were incubated in the presence or absence of bGH $(100 \mathrm{ng} / \mathrm{ml})$ for $20 \mathrm{~h}$. At $6 \mathrm{~h}$ before the end of incubation $\left[{ }^{3} \mathrm{H}\right]$ thymidine, $5 \mu \mathrm{Ci} / \mathrm{ml}$, or no isotope was added and cell number, DNA content, and $\left[{ }^{3} \mathrm{H}\right]$ thymidine incorporation were assessed. Each value represents the mean \pm SEM of four flasks.

† Significantly different from controls $(p<0.05)$.

\section{DISCUSSION}

The mechanism by which $\mathrm{GH}$ exerts its effects on skeletal growth is incompletely understood. Many lines of evidence indicate that this effect is mediated by somatomedin, either in a classical endocrine fashion (1-6) or by an autocrine or paracrine mechanism $(20,21)$. In addition, several recent reports have suggested a direct stimulation by GH (13-18). In the current studies, a direct effect of $\mathrm{GH}$ was sought in two tissues of particular significance to skeletal development: growth plate cartilage, the site of longitudinal skeletal growth, and articular cartilage, the cartilaginous component of joints.

Our data demonstrate that neither homologous nor heterologous GH stimulates either mitogenic or differentiated cell functions in bovine growth plate chondrocytes under a variety of experimental conditions. Similarly, rabbit articular and growth plate chondrocytes were unresponsive to either native or recombinant hGH.

The data further indicate that Sm-C/IGF-I stimulates both mitotic and differentiated cell functions in both physeal and articular chondrocytes. These effects are generated by nanomolar concentrations of Sm-C/IGF-I, a range consistent with a physiologic role in vivo.

The absence of chondrocyte stimulation in response to $\mathrm{GH}$ observed in our studies is in agreement with other recent studies $(10,12)$ that used embryonic avian (12) or fetal and adult human cartilage (10) under explant and clonal culture conditions. Our findings contrast with studies $(14,17)$ that used rabbit ear and rat rib growth chondrocytes under culture conditions reproduced in the present investigation. The apparent differences in these results may stem in part from differences in species (cow and rabbit versus rat) $(14,17)$, site of cartilage analyzed (limb versus rib) $(14,17)$, and type of cartilage used (physeal and articular versus ear) (14). In addition, the role of $\mathrm{GH}$ in early bovine development is not well established, and it is unknown to what degree the growth of young calves is GH dependent.

Reports addressing the ability of $\mathrm{GH}$ to stimulate cartilage may be divided into two categories according to their use of in vivo or in vitro conditions. So divided, such studies also tend to distribute according to the effect of $\mathrm{GH}$ on chondrocytes. Reports based on in vivo experiments are strikingly uniform in finding stimulation by $\mathrm{GH}$ of cartilage $(13,16,19,20,32)$. In contrast, reports of in vitro studies generally demonstrate lack of direct stimulation by $\mathrm{GH}(1,2,10,12,33)$. This in vivo-in vitro dichotomy is consistent with the hypothesis that the effects of $\mathrm{GH}$ observed in vivo are dependent on mediating substances or cofactors available in vivo but not available under the in vitro conditions tested thus far. Although several such mediators may exist, currently available data suggests that Sm-C/IGF-I plays a central role.

Classically, the somatomedin hypothesis has viewed $\mathrm{Sm}-\mathrm{C}$ / IGF-I as an endocrine factor, circulating with its binding protein(s) (6) and participating in hypothalamic and pituitary feedback mechanisms (34). More recent in vivo evidence suggests that the apparently direct stimulatory effect of $\mathrm{GH}$ on chondrocytes is mediated by local GH-dependent somatomedin production $(20,21)$. Although such an autocrine or paracrine phenomenon might be expected to manifest itself in vitro in the presence of $\mathrm{GH}$, the very low ratio of cell to medium volume under these conditions may dilute any GH-induced Sm-C/IGF-I to subthreshold levels. The present data are in accordance with the somatomedin hypothesis viewed either from a classical endocrine standpoint or from a paracrine/autocrine perspective.

We found that physeal chondrocytes from the proliferative zone were more responsive to Sm-C/IGF-I than their counterparts from the neighboring reserve zone. These data are consistent with the observation that proliferative zone cells have a greater Sm-C/IGF-I binding capacity than reserve zone cells (8) and with the demonstration in the rat that proliferative zone cells differ from other growth plate cells in their responsiveness to Sm-C/IGF-I (31). Taken together, these studies support a model in which the effect of Sm-C/IGF-I on the cell populations of the growth plate is dependent on the cell population's stage of maturational development.

The dual effector theory of GH action recently advanced by Green et al. (22) postulates that $\mathrm{GH}$ promotes precursor cell differentiation and that this differentiation renders the cells susceptible to clonal expansion under the influence of Sm-C/IGF- 
Table 3. Effect of $b G H$ and $S m-C / I G F-I$ on rabbit articular chondrocytes cultured in serum-free medium*

\begin{tabular}{lcccc}
\hline & $\begin{array}{c}\text { Cell no. } \\
\left(\times 10^{-6} / \text { well }\right)\end{array}$ & $\begin{array}{c}\text { DNA } \\
(\mu \mathrm{g} / \text { well })\end{array}$ & $\begin{array}{c}\left.{ }^{3} \mathrm{H}\right] \text { thymidine } \\
(\mathrm{cpm} / \text { well })\end{array}$ & $\begin{array}{c}{\left[{ }^{35} \mathrm{~S}\right] \text { sulfate }} \\
\left(\times 10^{-4} \text { disintegration/well }\right)\end{array}$ \\
\hline No. of wells & 6 & 4 & 6 & 6 \\
Control & $7.2 \pm 0.6$ & $0.80 \pm 0.07$ & $1316 \pm 100$ & $20.74 \pm 2.21$ \\
hGH $(100 \mathrm{ng} / \mathrm{ml})$ & $8.9 \pm 0.8$ & $0.66 \pm 0.11$ & $1428 \pm 30$ & $18.43 \pm 2.90$ \\
Sm-C/IGF-I $(10 \mathrm{ng} / \mathrm{ml})$ & $12.3 \pm 1.3 \dagger$ & $1.06 \pm 0.08 \ddagger$ & & $43.50 \pm 3.50 \S$ \\
\hline
\end{tabular}

* Rabbit articular chondrocytes cultured in serum-free medium were incubated in the presence or absence of hGH (100 ng/ml) or Sm-C/IGF-I $(10 \mathrm{ng} / \mathrm{ml})$ for 5 days. At six h before the end of incubation $\left[{ }^{3} \mathrm{H}\right]$ thymidine, $5 \mu \mathrm{Ci} \mathrm{ml} \mathrm{Na}{ }^{35} \mathrm{SO}_{4}, 1.5 \mu \mathrm{Ci} / \mathrm{ml}$ or no isotope was added, and cell number, DNA content, $\left[{ }^{3} \mathrm{H}\right]$ thymidine and $\left[{ }^{35} \mathrm{~S}\right]$ sulfate incorporation were assessed. Each value is the mean $\pm \mathrm{SEM}$ of four or six wells as indicated.

$\dagger$ Values significantly different from controls, $p<0.01$.

$\$$ Values significantly different from controls, $p<0.05$.

$\S$ Values significantly different from controls, $p<0.001$.

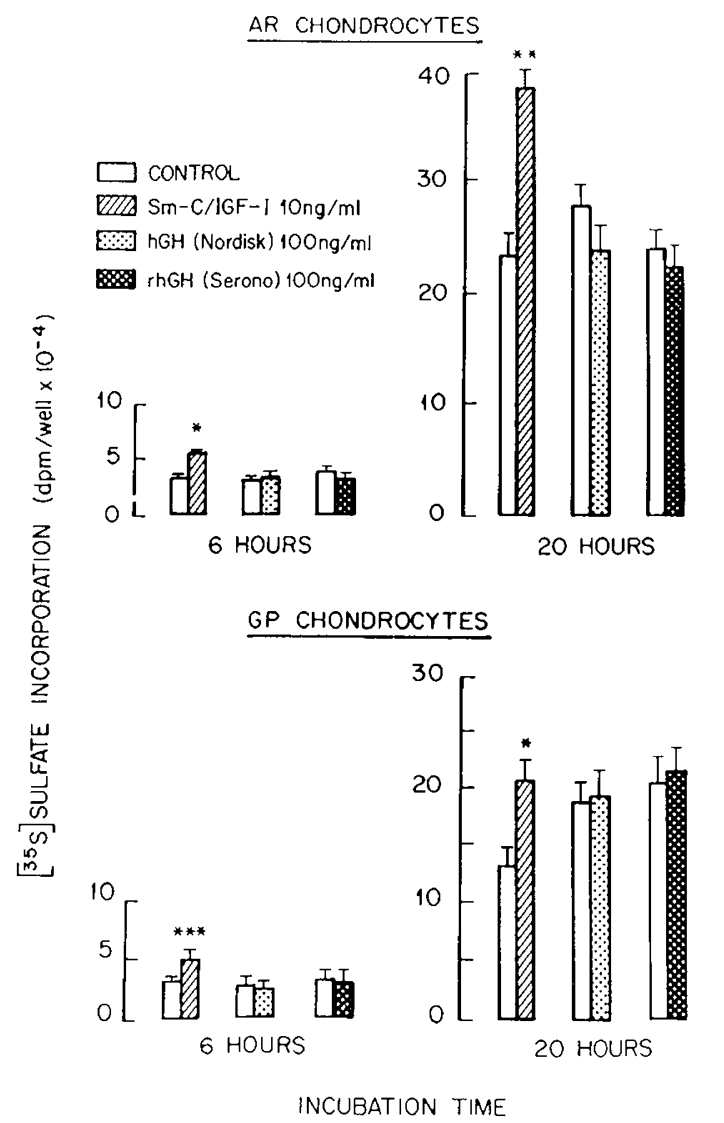

Fig. 5. Effect of Sm-C/IGF-I, hGH or met-rhGH on $\left[{ }^{35} \mathrm{~S}\right]$ sulfate incorporation into proteoglycans obtained from rabbit articular (upper panel) and rabbit growth plate (lower panel) chondrocyte primary cultures. Both types of chondrocytes were used at confluency after $20 \mathrm{~h}$ deprivation of FCS. $\left[{ }^{35}\right.$ S $]$ sulfate incorporation was performed during a period of 6 or $20 \mathrm{~h}$ as indicated. Each value represents the mean \pm SEM of six wells. Each treated group was compared to its control. ${ }^{*} p<0.02$, ${ }^{* *} p<0.01,{ }^{* * *} p<0.001$.

I. The finding in the present studies that proliferative zone cells are more responsive to $\mathrm{Sm}-\mathrm{C} / \mathrm{IGF}-\mathrm{I}$, and in previous studies that these cells have a higher Sm-C/IGF-I binding capacity than reserve zone chondrocytes (8), is consistent with this theory. However, the present data also reveal that reserve zone chondrocytes, the presumed "germinal" cells of the growth plate, are capable of responding to Sm-C/IGF-I. This responsiveness would not be inconsistent with the dual effector theory if it reflects a differentiated state conferred on cells preexperimentally by $\mathrm{GH}$ in vivo, if certain reserve zone cells are not, in fact, stem cells, or if culture conditions alter their pattern of susceptibility. Nevertheless, these data suggest that the role of Sm-C/IGF-I in skeletal development is complex and may be diverse both in the cellular functions it regulates and the cell populations regulated. Further investigation will be required to define fully the relative importance of endocrine and paracrine/autocrine actions of $\mathrm{Sm}-\mathrm{C} /$ IGF-I on skeletal growth and its relationship to $\mathrm{GH}$.

Acknowledgments. The authors thank David Schoenfeld, Ph.D., Department of Biostatistics, Massachusetts General Hospital,for statistical analysis of data, Ms. Allie McGuinness for expert assistance in preparing the manuscript, and Judson J. Van Wyk, M.D., for discovering the compatibility of the coauthors' work.

\section{REFERENCES}

1. Salmon Jr WD, Daughaday WH 1957 A hormonally controlled serum factor which stimulates sulfate incorporation by cartilage in vitro. J Lab Clin Med 49:825-836

2. Phillips LS, Vassilopoulou-Sellin R 1980 Somatomedins I. N Engl J Med 302:372-380; 438-446

3. Van Wyk JJ, Underwood LE, Hintz RL, Clemmons DR, Voina SJ, Weaver RP 1974 The somatomedins: a family of insulin-like hormones under growth hormone control. Recent Prog Horm Res 30:259-295

4. Schoenle E, Zapf J, Humbel RE, Froesch RE 1982 Insulin-like growth factor I stimulates growth in hypophysectomized rats. Nature 296:252-253

5. Copeland KC, Underwood LE, Van Wyk JJ 1980 Induction of immunoreactive somatomedin- $C$ in human serum by growth hormone: dose response relationships and effect on chromatographic profiles. J Clin Endocrinol Metab 50:690-697

6. Berelowitz M, Szabo M, Frohman LA, Firestone S, Chu L 1981 Somatomedin$\mathrm{C}$ mediates growth hormone negative feedback by effects on both the hypothalmus and the pituitary. Science 212:1279-1281

7. Trippel SB, Van Wyk JJ, Foster MB, Svoboda ME 1983 Characterization of a specific somatomedin-C receptor on isolated bovine growth plate chondrocytes. Endocrinology 112:2128-2136

8. Trippel SB, Van Wyk JJ, Mankin JJ 1986 Localization of somatomedin-C binding to bovine growth plate chondrocytes in situ. J Bone Joint Surg 68A:897-903

9. Ash P, Francis MJO 1975 Response of isolated rabbit articular and epiphyseal chondrocytes to rat liver somatomedin. J Endocrinol 66:71-78

10. Vetter U, Zapf J, Heit W, Helbing G, Heinze E, Froesch EF, Teller WM 1986 Human fetal and adult chondrocyte. Effect of insulin-like growth factors I and II, insulin and growth hormone on clonal growth. J Clin Invest 7:19031908

11. Eigenmann JE, Patterson DF, Froesch EF 1984 Body size parallels insulin-like growth factor I levels but not growth hormone capacity. Acta Endocrinol 106:448-453

12. Burch W, Corda G, Leung FC 1985 Homologous and heterologous growth hormone fail to stimulate avian cartilage growth in vitro. J Clin Endocrinol Metab 60:747-750

13. Isaksson OGP, Jansson J-O, Gause IAM 1982 Growth hormone stimulates longitudinal bone growth directly. Science 216:1237-1239.

14. Madsen K, Friberg U, Ross P, Eden S, Isaksson O 1983 Growth hormone stimulates the proliferation of cultured chondrocytes from rabbit ear and rib growth cartilage. Nature 304:545-547

15. Eden S, Isaksson OGP, Madsen K, Friberg U 1983 Specific binding of growth hormone to isolated chondrocytes from rabbit ear and epiphyseal plate. Endocrinology 112:1127-1129

16. Russell SM, Spencer EM 1985 Local injections of human or rat growth hormone or of purified human somatomedin-C stimulate unilateral tibial epiphyseal growth in hypophysectomized rats. Endocrinology 116:25632567

17. Madsen K, Makower A-M, Friberg U, Eden S, Isaksson O 1985 Effect of human growth hormone on proteoglycan synthesis in cultured rat chondrocytes. Acta Endocrinol 108:338-342 
18. Lindahl A, Isgaard J, Nilsson A, Isaksson O 1986 Growth hormone potentiates colony formation of epiphyseal chondrocytes in suspension culture. Endocrinology 118:1843-1848

19. Schlechter NL, Russell SM, Greenberg S, Spender EM, Nicoll CS 1986 A direct effect of growth hormone in rat hind limb shown by arterial infusion. Am J Physiol 250:E231-235

20. Schlechter NL, Russell SM, Spencer EM, Nicoll CS 1986 Evidence suggesting that the direct growth-promoting effect of growth hormone on cartilage in vivo is mediated by local production of somatomedin. Proc Natl Acad Sci USA 83:7932-7934

21. Nilsson A, Isgaard J, Lindahl A, Dahlstrom A, Skettner A, Isaksson O 1986 Regulation by growth hormone of the number of chondrocytes containing IGF-I in the rat growth plate. Science 233:571-574

22. Green H, Morikowa M, Nixon T $1985 \mathrm{~A}$ dual effector theory of growthhormone action. Differentiation 29:195-198

23. Zezulak KM, Green $\mathrm{H} 1986$ The generation of insulin-like growth factorsensitive cells by growth hormone action. Science 233:551-553

24. Clemmons DR, Van Wyk JJ 1981 Somatomedin and platelet derived growt factor stimulate human fibroblast replication. J Cell Physiol 106:361-367

25. Russell WE, Van Wyk JJ, Pledger WJ 1984 Inhibition of mitogenic effects of plasma by a monoclonal antibody to somatomedin-C. Proc Natl Acad Sci USA 81:2389-2392

26. Furlanetto RW, Underwood LE, Van Wyk JJ, D'Ercole AJ 1977 Estimation of somatomedin-C levels in normals and patients with pituitary disease by radioimmunoassay. J Clin Invest 60:648-657

27. Green Jr WT 1971 Behavior of articular chondrocytes in culture. Clin Orthop $75: 248-260$

28. Burton K 1956 A study of the conditions and mechanism of the diphenylamine reaction for the colorimetric estimation of DNA. Biochem $\mathrm{J}$ 62:315-323

29. Kapuscinki J, Skoczylas B 1977 Simple and rapid fluorimetric method for DNA microassay. Anal Biochem 83:252-257

30. Corvol MT, Dumontier MF, Rappaport R, Guyda H, Posner BI 1978 The effect of a somatomedin peptide (ILAs) on the sulfation of proteoglycans from articular and growth plate chondrocytes in culture. Acta Endocrinol 89:263-275

31. Hill DJ 1979 Stimulation of cartilage zones of the calf costochondral growth plate in vitro by growth hormone dependent plasma somatomedin activity. J Endocrinol 83:219-227

32. Skottner A, Clark RG, Robinson ICAF, Fryklund L 1987 Recombinant human insulin-like growth factor: testing the somatomedin hypothesis in hypophysectomized rats. J Endocrinol 112:123-132

33. Daughaday WH, Reeder C 1966 Synchronous activation of DNA synthesis in hypophysectomized rat cartilage by growth hormone. J Lab Clin Med 68:357-368

34. Hintz RI 1984 Plasma forms of somatomedin and the binding protein phenomenon. Clin Endocrinol Metab 13:31-42 